\title{
Intestinal Starch Digestion in Sheep Fed Different Rations with Abomasal Starch Infusion
}

\author{
Kohzo Taniguchi, Satoshi Miyake, Taketo Obitsu \\ and Yoji YaMATANI
}

Faculty of Applied Biological Science, Hiroshima University, Higashihiroshima-shi 724

(Received July 23, 1990)

\begin{abstract}
Four sheep were each fitted with an abomasal simple cannula and an ileal re-entrant cannula, and fed four rations at the maintenance energy level. The rations consisted of $30 \%$ concentrate and $70 \%$ chopped hay or $70 \%$ alfalfa meal pellets, and $70 \%$ concentrate and $30 \%$ chopped hay or $30 \%$ alfalfa meal pellets on a digestible energy basis. The concentrate contained mainly ground corn and soybean meal. Two digestion trials for each ration were conducted ; in the first trial, animals were fed ration alone, and then in the second were fed the same ration with continuous infusion of purified corn starch into the abomasum, averaging $113 \mathrm{~g}$ per day, equivalent to 0.2 times maintenance energy. The ingested starch digestibilities for the high-roughage rations were lower than those for the high concentrate rations in the rumen and small intestine, when expressed as percentages of the entered amount. Conversely, the large-intestinal digestibilities for the high-roughage rations became higher, but the total digestibilities tended to be lower in comparison with the high-concentrate rations. The treatment means of the small-intestinal digestibility of infused starch decreased from $86.0 \%$ with 30 $\%$ chopped hay to $75.1 \%$ with $70 \%$ chopped hay as the amount of neutral detergent fiber entering intestine increased. However, the ration containing a high level of concentrate and a low amount of alfalfa meal pellets showed a considerably low digestibility of $45 \%$, despite having the lowest amount of intestinal fiber. In such a ration, a higher content of long-chain polymers in $\alpha$-glucoside fractions of ileal digesta suggested a lower action of $\alpha$-amylase in the small intestine. As the greater digestibility of infused starch in the large intestine compensated for the lower digestibility in the small intestine, the total intestinal digestibility for each treatment was over $93 \%$, and not different. It is thus considered that starch digestion is not affected by other ingested components throughout the whole intestine, but is variable in the small intestine.
\end{abstract}

Anim. Sci. Technol. (Jpn.) 62 (3) : 253-262, 1991

Key words : sheep, digestion, starch, small intestine, fiber

Most carbohydrates consumed by ruminants are subjected to microbial fermentation in the rumen. Animals cannot utilize structural carbohydrates without the microbial fermentation process, although they can deal with nonstructural carbohydrates through enzymatic digestion in the small intestine. The energetic efficiency of non-structural carbohydrates for the host should be higher when digested in the small intestine than when fermented extensively in the rumen ${ }^{3,13}$, provided that the majority of them entering the small intestine are digested prior to arrival at the large intestine. However, the capacity of ruminants for smallintestinal digestion of starch, which accounts for the major fraction of dietary non-struc- 
Taniguchi, Miyake, Obitsu and Yamatani

tural carbohydrates, is inferior to that of non-ruminant animals ${ }^{14,17}$. Many factors influencing starch digestion in the ruminant small intestine have been proposed ${ }^{18)}$, although there have been few studies on the effects of dietary fibrous components. The fibrous fractions are digested in the rumen by microorganisms to some extent but in practice a considerable quantity of ruminally undigested fiber still reaches the small intestine, and therefore may interfere with intestinal starch digestion.

The purpose of this study was to compare the effects of the roughage and concentrate ratio on the site of digestion of ground corn, and to investigate further the effect of fiber on the small- and large-intestinal digestion of starch infused into the abomasum.

Preliminary accounts of some of this work have already been published ${ }^{23)}$.

\section{Materials and Methods}

Four Suffolk sheep, averaging $49 \mathrm{~kg}$ (46$53 \mathrm{~kg}$ ) in body weight, were fitted with an abomasal simple cannula and a terminal ileum re-entrant cannula, placed in metabolism crates, and fed four rations.

The rations consisted of $30 \%$ concentrate and $70 \%$ chopped (about $5 \mathrm{~cm}$ in length) Italian ryegrass hay $(\mathrm{HH})$ or $70 \%$ alfalfa meal pellets (HP), and $70 \%$ concentrate and $30 \%$ chopped hay $(\mathrm{LH})$ or $30 \%$ alfalfa meal pellets (LP) on a digestible energy basis (Table 1). The concentrate contained mainly ground corn and soybean meal. As the digestible energy content was different among these rations, each ration was fed to be an isoenergy level adequate for maintenance ${ }^{163}$. The soybean meal content in the concentrate was adjusted to be an isonitrogen intake in each ration. Mineral supplements were added for adjusting the contents of calcium and phosphate in the rations. The rations were offered in two equal portions at 0900 and $1800 \mathrm{~h}$. The chemical compositions of the rations are shown in Table 1.
Table 1. Ingredients and chemical compositions of rations

\begin{tabular}{lrrrrr}
\hline Item & HH & LH & HP & LP \\
\hline & & & & \\
Ingredient & & & & \\
Italian ryegrass hay & 78.5 & 42.0 & - & - \\
Alfalfa meal pellets & - & - & 76.7 & 38.0 \\
Ground corn & & & & & \\
Soybean meal & 4.2 & 33.8 & 22.6 & 45.8 \\
Tricalcium phosphate & 1.0 & 1.3 & - & 1.7 \\
Calcium carbonate & 1.0 & 1.3 & - & - \\
Monosodium phosphate & - & - & 0.7 & - \\
Chemical composition & & & & \\
Crude protein & 14.5 & 17.9 & 17.0 & 19.4 \\
Neutral detergent fiber & 56.0 & 34.7 & 34.8 & 22.8 \\
Starch 2 & 6.7 & 27.5 & 18.2 & 35.1 \\
$\quad$ Glucan & 4.0 & 25.1 & 17.5 & 33.7 \\
Dextrin & 0.2 & 1.0 & 0.6 & 1.3 \\
Glucose & 2.5 & 1.4 & 0.2 & 0.2
\end{tabular}

Energy content

\begin{tabular}{lllll} 
Gross energy & 4.0 & 4.2 & 4.2 & 4.3 \\
Digestible energy & 2.5 & 3.0 & 2.9 & 3.5 \\
\hline
\end{tabular}

On a dry matter basis.

${ }^{1}$ Ground corn contains $2 \%$ fish meal.

2Starch was determined as a total $\alpha$-gluco-

side and each fraction was expressed in terms of glucose equivalent.

Purified corn starch averaging $113 \mathrm{~g}$ per day, equivalent to 0.2 times the maintenance energy requirement, was used for abomasal infusion. The starch, suspended in $1 l$ distilled water using a magnetic stirrer, was infused by means of a peristaltic pump. The infusion rate was maintained at a constant level throughout the infusion period. The experimental design adopted was a $4 \times 4$ Latin square, in which each square consisted of two digestion trials; namely, the first trial was for each ration and the second for infused starch. Each digestion trial was carried out by means of an indicator method using $\mathrm{Cr}_{2} \mathrm{O}_{3}$, administered into the rumen at feeding time, and consisted of a 14-day preliminary period followed by a 4-day collection period. During each collection period, eight ileal samples, eight abomasal samples 
and all the feces were collected, but during starch infusion period the abomasal samples were not taken. The obtained digesta samples were composited and lyophilized for subsequent analyses. Blood samples were also taken from the jugular vein at 0830 and $1100 \mathrm{~h}$ on the final day for measurement of serum glucose level.

Feed, fecal, abomasal and ileal samples were analyzed for crude protein by the semi-micro KJELDAHL method, calorie using the bombcalorimeter (CA-3, Shimazu Seisakusho LTD.), neutral detergent fiber (NDF) by the modified GoERING and VAN SOEsT ${ }^{7)}$ method, and starch by the following method: samples for starch analysis were hydrolysed with exo-1, 4-glucosidase [EC 3.2.1.3] and then determined by the glucose oxidase method as $\alpha$-glucoside ${ }^{9)}$. In addition, the total $\alpha$-glucoside in feed and ileal digesta was fractionated into glucan (longchain polymers, precipitated by hot ethanol), dextrin (shorter-chain polymers, soluble in hot ethanol) and unpolymerized glucose ${ }^{15)}$. Fractionation was achieved by determining the total $\alpha$-glucoside (starch), the ethanol-soluble $\alpha$-glucoside fraction (dextrin plus glucose), and glucose. Glucan was estimated by subtracting dextrin and glucose from starch. In order that such estimation could be made, all fractions had to be expressed in terms of glucose equivalent, which is the equivalent amount of glucose formed from the fraction upon its hydrolysis. Blood serum glucose was analyzed by the glucose oxidase method ${ }^{121}$. All digesta samples including feces were also analyzed for $\mathrm{Cr}_{2} \mathrm{O}_{3}{ }^{27)}$ in order to estimate the flow of chemical components in each segment of the digestive tract and to calculate digestibility.

The digestibility of infused starch in the small and the large intestines was estimated by the difference in the amount of starch without and with infusion. Digestibilities of nutrients in each segment of digestive tract were calculated by dividing the disappearance in the segment by the intake or the entered amount.
Data were subjected to standard statistical analysis procedures for Latin square designs. Test of significance among treatment means were accomplished by use of TukEy's q-test.

\section{Results and Discussion}

Intakes of dry matter, gross energy, digestible energy, crude protein, NDF and starch, and the amounts of each left in the various parts of the digestive tract of sheep given four rations are shown in Table 2. Furthermore, their digestibilities in the rumen, the small intestine, the large intestine and the total tracts are shown in Table 3 as percentages of intake, and the digestibilities of crude protein and starch in the small intestine and large intestine expressed as percentages of amount entered into the segment are shown in Table 4.

Dry matter and gross energy

Dry matter intake for $\mathrm{HH}$ and $\mathrm{HP}$ of the high-roughage ration appeared to be higher $(\mathrm{P}<0.05)$ than those for LH and LP of the high-concentrate ration. The digestibilities of dry matter and gross energy were higher for $\mathrm{LH}$ and LP than for $\mathrm{HH}$ and HP in the small intestine and the total digestive tract, and the total digestible energy intake was not different among the four rations. The proportion of small-intestinal digestion among total digestion increased for high-concentrate rations, especially for $\mathrm{LH}$, in which half of the total digestible dry matter was digested in the small intestine. This suggests that small-intestinal digestion becomes more important for a highconcentrate ration than for a high-roughage ration.

Crude protein

Net gain of nitrogen for the HI, LII and HP rations was observed due to nitrogen recycling in the stomach, but $13 \%$ of the dietary nitrogen in LP was lost from the stomach. Recycling endogenous nitrogen can enter the rumen and also the post ruminal tract. The ruminal route is influenced by a number of dietary factors, for example nitrogen or 
Table 2. Intake and flow of nutrients through each part of the digestive tract in sheep without starch infusion

\begin{tabular}{|c|c|c|c|c|}
\hline \multirow{2}{*}{ Item } & \multicolumn{4}{|c|}{ Treatment } \\
\hline & $\mathrm{HH}$ & LH & $\mathrm{HP}$ & LP \\
\hline \multicolumn{5}{|l|}{ Dry matter (g/day) } \\
\hline Intake & $859 \pm 38$ & $703 \pm 32$ & $738 \pm 3$ & $648 \pm 29$ \\
\hline Abomasum & $556 \pm 19$ & $502 \pm 23$ & $446 \pm 13$ & $327 \pm 39$ \\
\hline Terminal ileum & $371 \pm 20$ & $253 \pm 21$ & $324 \pm 18$ & $157 \pm 27$ \\
\hline Exiting rectum & $306 \pm 24$ & $197 \pm 32$ & $222 \pm 15$ & $118 \pm 29$ \\
\hline \multicolumn{5}{|c|}{ Gross energy (kcal/day) } \\
\hline Intake & $3443 \pm 153$ & $2930 \pm 131$ & $3086 \pm 137$ & $2780 \pm 123$ \\
\hline Abomasum & $2042 \pm 96$ & $1842 \pm 95$ & $1882 \pm 110$ & $1379 \pm 166$ \\
\hline T'erminal ileum & $1427 \pm 56$ & $961 \pm 106$ & $1318 \pm 89$ & $619 \pm 89$ \\
\hline Exiting rectum & $1278 \pm 49$ & $807 \pm 82$ & $954 \pm 128$ & $497 \pm 107$ \\
\hline \multicolumn{5}{|l|}{ Digestible energy } \\
\hline Intake (kcal/day) & $2165 \pm 101$ & $2123 \pm 106$ & $2132 \pm 133$ & $2283 \pm 115$ \\
\hline \multicolumn{5}{|c|}{ Crude protein (g/day) } \\
\hline Intake & $125 \pm 5$ & $126 \pm 6$ & $126 \pm 6$ & $126 \pm 6$ \\
\hline Abomasum & $165 \pm 13$ & $167 \pm 11$ & $145 \pm 14$ & $109 \pm 7$ \\
\hline Terminal ileum & $60 \pm 6$ & $49 \pm 5$ & $59 \pm 6$ & $35 \pm 3$ \\
\hline Exiting rectum & $45 \pm 6$ & $34 \pm 5$ & $38 \pm 1$ & $29 \pm 3$ \\
\hline \multicolumn{5}{|c|}{ Neutral detergent fiber ( $\mathrm{g} /$ day $)$} \\
\hline Intake & $481 \pm 22$ & $244 \pm 11$ & $256 \pm 12$ & $148 \pm 7$ \\
\hline Abomasum & $263 \pm 14$ & $146 \pm 9$ & $201 \pm 16$ & $93 \pm 11$ \\
\hline Terminal ileum & $263 \pm 12$ & $144 \pm 8$ & $150 \pm 13$ & $66 \pm 9$ \\
\hline Exiting rectum & $239 \pm 12$ & $123 \pm 6$ & $150 \pm 13$ & $66 \pm 9$ \\
\hline \multicolumn{5}{|l|}{ Starch (g/day) } \\
\hline Intake & $57 \pm 2$ & $193 \pm 9$ & $134 \pm 6$ & $228 \pm 10$ \\
\hline Abomasum & $25 \pm 6$ & $58 \pm 8$ & $40 \pm 7$ & $26 \pm 6$ \\
\hline Terminal ileum & $17 \pm 3$ & $21 \pm 6$ & $27+2$ & $14 \pm 3$ \\
\hline Exiting rectum & $9 \pm 3$ & $14 \pm 3$ & $14 \pm 4$ & $8 \pm 2$ \\
\hline
\end{tabular}

Figures are mean values \pm standard deviation for 4 sheep.

readily degradable carbohydrate content, but the mechanisms responsible remain unclear ${ }^{21)}$. The small-intestinal digestibility of crude protein varied inversely with disappearnce from the rumen, ranging from $58 \%$ of treatment mean to $94 \%$ (Table 3 ), but when expressed as a percentage of the amount entering the abomasum, the range was $59 \%$ to $71 \%$ (Table 4). The total digestibilities of crude protein for LH and LP were higher than those for $\mathrm{HH}$ and $\mathrm{HP}$, as noted for dry matter and gross energy.

Neutral detergent fiber
With regard to the NDF digestion when sheep consumed the rations containing chopped hay, the ruminal digestibility was higher for HH than for LH, but the total digestibility was not different because of compensatory digestion in the large intestine for the reduced ruminal digestion. It is well known that when readily fermentable carbohydrates (RFC) are added to forage basal diet, fiber digestion is depressed $^{22)}$. Several theories have been advanced to explain the depressive effects of $\mathrm{RFC}$ : a preference by rumen microbes for RFC rather than fiber components; a decrease in 
Table 3. Nutrient digestibility in each part of the digestive tract of sheep fed different rations without starch infusion ${ }^{1}$

\begin{tabular}{|c|c|c|c|c|}
\hline \multirow{2}{*}{ Item } & \multicolumn{4}{|c|}{ Treatments } \\
\hline & $\mathrm{HH}$ & $\mathrm{LH}$ & $\mathrm{HP}$ & LP \\
\hline \multicolumn{5}{|l|}{ Dry matter } \\
\hline Rumen & $35.2 \pm 2.1^{a}$ & $28.6 \pm 4.4^{b}$ & $39.6 \pm 2.0^{c}$ & $49.5 \pm 6.5^{d}$ \\
\hline Small intestine & $21.6 \pm 1.5^{a}$ & $35.5 \pm 4.7^{b}$ & $16.6 \pm 3.2^{\mathrm{c}}$ & $26.2 \pm 2.8^{\mathrm{d}}$ \\
\hline Large intestine & $7.6 \pm 2.2^{\mathrm{ac}}$ & $7.9 \pm 0.7^{\mathrm{a}}$ & $13.9 \pm 3.9^{\circ}$ & $6.1 \pm 0.9^{c}$ \\
\hline Total tract & $64.4 \pm 2.8^{a}$ & $72.0 \pm 4.4^{\mathrm{b}}$ & $70.0 \pm 2.7^{b}$ & $81.8 \pm 4.9^{c}$ \\
\hline \multicolumn{5}{|l|}{ Gross energy } \\
\hline Rumen & $40.7 \pm 2.6^{\mathrm{a}}$ & $37.1 \pm 0.9^{b}$ & $39.0 \pm 4.2^{\mathrm{ab}}$ & $50.3 \pm 5.6^{c}$ \\
\hline Small intestine & $17.9 \pm 5.1^{\mathrm{a}}$ & $30.1 \pm 6.8^{b}$ & $18.3 \pm 2.5^{\mathrm{a}}$ & $27.4 \pm 4.9^{b}$ \\
\hline Large intestine & $4.3 \pm 2.7^{\mathrm{a}}$ & $5.3 \pm 3.0^{a}$ & $11.8 \pm 3.4^{b}$ & $4.4 \pm 2.1^{\mathrm{a}}$ \\
\hline Total tract & $62.9 \pm 1.5^{a}$ & $72.5 \pm 2.9^{b}$ & $69.1 \pm 4.6^{b}$ & $82.1 \pm 5.0^{\mathrm{c}}$ \\
\hline \multicolumn{5}{|l|}{ Crude protein } \\
\hline Rumen & $-32.2 \pm 8.9^{a}$ & $-32.6 \pm 10.0^{a}$ & $-15.6 \pm 6.8^{b}$ & $13.7 \pm 6.3^{c}$ \\
\hline Small intestine & $84.6 \pm 3.9^{\mathrm{a}}$ & $93.6 \pm 5.8^{a}$ & $68.2 \pm 3.8^{b}$ & $58.3 \pm 2.6^{c}$ \\
\hline Large intestine & $12.0 \pm 2.2^{\mathrm{a}}$ & $10.4 \pm 0.9^{3}$ & $17.0 \pm 6.8^{\mathrm{a}}$ & $5.2 \pm 2.1^{b}$ \\
\hline Total tract & $64.415 .9^{a}$ & $73.2 \pm 9.1^{\mathrm{ab}}$ & $69.6 \pm 4.0^{\mathrm{a}}$ & $77.1 \pm 3.5^{b}$ \\
\hline \multicolumn{5}{|c|}{ Neutral detergent fiber } \\
\hline Rumen & $45.3 \pm 0.8^{a}$ & $40.2 \pm 3.9^{b}$ & $21.9 \pm 6.2^{c}$ & $37.0 \pm 4.6^{b}$ \\
\hline Small intestine & $0.0 \pm 1.7$ & $0.6 \pm 1.1$ & $5.1 \pm 3.3$ & $0.5 \pm 1.4$ \\
\hline Large intestine & $5.0 \pm 2.0^{\mathrm{a}}$ & $8.8 \pm 1.9^{a}$ & $14.7 \pm 3.9^{b}$ & $17.9 \pm 6.0^{b}$ \\
\hline Total tract & $50.3 \pm 1.0^{\text {ab }}$ & $49.6 \pm 3.9^{\mathrm{ab}}$ & $41.7 \pm 7.5^{a}$ & $55.4 \pm 4.7^{b}$ \\
\hline \multicolumn{5}{|l|}{ Starch } \\
\hline Rumen & $55.9 \pm 7.3^{\mathrm{a}}$ & $69.8 \pm 4.7^{b}$ & $69.9 \pm 5.2^{b}$ & $88.5 \pm 3.8^{c}$ \\
\hline Small intestine & $14.2 \pm 3.7^{\mathrm{ab}}$ & $19.3 \pm 6.3^{a}$ & $9.8 \pm 2.8^{b c}$ & $5.3 \pm 2.1^{\mathrm{c}}$ \\
\hline Large intestine & $14.5 \pm 2.8^{\mathrm{a}}$ & $3.7 \pm 0.9^{b}$ & $10.0 \pm 2.6^{\mathrm{a}}$ & $2.9 \pm 1.0^{b}$ \\
\hline Total tract & $84.5+4.9^{a}$ & $92.8 \pm 2.1^{b}$ & $89.6 \pm 2.9^{\mathrm{ab}}$ & $96.7 \pm 1.2^{\mathrm{c}}$ \\
\hline
\end{tabular}

Figures are mean values \pm standard deviation for 4 sheep.

$a, b, c, d$ Mean values in the same row with different superscripts differ significantly $(P<0.05)$.

${ }^{1}$ Expressed as a percentage of intake.

ruminal $\mathrm{pH}$ caused by rapid $\mathrm{RFC}$ fermentation, with resulting depression of fiber degradation; competition for essential nutrients, resulting in preferential proliferation of RFC-digesting microbes ${ }^{10)}$. However, when sheep consumed the rations containing pelleted alfalfa meal, the digestibility of NDF for HP was rather lower than that for LP in both the rumen and the total tract. As the passage rate of roughage increased not only with grinding and pelleting but also with increased fiber intake ${ }^{1}$, the present depression of NDF digestibility for
HP was probably caused by shortening of retention time in the rumen with increased pellet intake. The different tendency shown in NDF digestion between HH to $\mathrm{LH}$ and HP to LP is probably caused from the different physical form, and pellet may easily pass the reticulo-omasal orifice of sheep compared with chopped hay. The large intestinal digestion of NDF with pellet ration was higher than that with hay ration. This agrees with the report by ARMSTRONG and SMITHARD ${ }^{2)}$, who indicated that grinding and pelieting of roughage 
Table 4. Digestibility of ingested starch and crude protein and infused starch in the intestine of sheep fed different rations

\begin{tabular}{|c|c|c|c|c|}
\hline \multirow{2}{*}{ Item } & \multicolumn{4}{|c|}{ Treatments } \\
\hline & $\mathrm{HH}$ & $\mathrm{L} . \mathrm{H}$ & HP & LP \\
\hline & & & & \\
\hline \multicolumn{5}{|c|}{ Ingested crude protein } \\
\hline Small intestine & $64.0 \pm 2.0^{\circ}$ & $70.5 \pm 4.1^{b}$ & $59.0 \pm 2.9^{\mathrm{c}}$ & $67.5 \pm 2.9^{\mathrm{ab}}$ \\
\hline Large intestine ${ }^{1}$ & $25.5 \pm 3.1^{\mathrm{a}}$ & $31.4 \pm 2.6^{\mathrm{b}}$ & $34.9 \pm 14.7^{\mathrm{ab}}$ & $18.1 \pm 6.4^{\mathrm{a}}$ \\
\hline \multicolumn{5}{|l|}{ lngested starch } \\
\hline Small intestine ${ }^{1}$ & $32.4 \pm 10.6^{2}$ & $62.5 \pm 14.7^{b}$ & $31.7 \pm 9.0^{a}$ & $45.3 \pm 10.3^{* b}$ \\
\hline Large intestine ${ }^{1}$ & $48.9 \pm 7.5$ & $30.7 \pm 23.5$ & $48.1 \pm 12.1$ & $44.1 \pm 21.8$ \\
\hline \multicolumn{5}{|l|}{ Infused starch } \\
\hline Small intestine ${ }^{2}$ & $75.1 \pm 1.6^{\mathrm{a}}$ & $86.0 \pm 5.7^{b}$ & $79.0 \pm 6.6^{\mathrm{ab}}$ & $44.7 \pm 15.7^{c}$ \\
\hline Large intestine ${ }^{2}$ & $21.1 \pm 5.3^{\mathrm{a}}$ & $10.6 \pm 7.3^{b}$ & $15.8 \pm 6.3^{\mathrm{ab}}$ & $48.5 \pm 14.4^{c}$ \\
\hline Total intestine ${ }^{2}$ & $96.2 \pm 6.8$ & $96.6 \pm 1.9$ & $94.8 \pm 3.3$ & $93.2 \pm 3.6$ \\
\hline
\end{tabular}

Figures are mean values \pm standard deviation for 4 sheep.

$a, b, c$ Mean values in the same row with different superscripts differ significantly $(P<0.05)$.

${ }^{1}$ Expressed as a percentage of the amount entered the segment of digestive tract.

${ }^{2}$ Expressed as a percentage of the amount infused into the abomasum.

resulted in an increase of fiber fermentation in the cecum.

Starch

Starch intake varied from 57 to $228 \mathrm{~g}$ per day depending on the ration, but the amounts entering the abomasum were within a narrower range of $25-58 \mathrm{~g}$. Starch digestibility in the rumen and the total tract was higher for the high concentrate ration than for the highroughage ration irrespective of the kind of roughage used. This is consistent with the results of TUCKER et al. ${ }^{26)}$, who fed sheep different rations of ground corn and ground alfalfa hay. The depression of total starch digestion was mainly attributed to ruminal digestion, since the proportion of ruminal starch digestion relative to total digestion accounted for $66 \%$ of $\mathrm{HH}$ to $92 \%$ of LP. As factors affecting the amount of starch entering the small intestine, the species, processing ${ }^{25}$ and intake level ${ }^{26)}$ of grain have been indicated. In addition to such factors, the amount and physical form of roughage contained in a ration would also be involved, as the present result shows. GoETsCh et al. ${ }^{8)}$ also observed that digestion of ground corn in the rumen tended to be greater for short than for long or medium physical forms of hay in the ration. The LP ration having the highest digestibility for starch in the rumen showed the lowest digestibility in the small intestine, although there was little difference in the smallintestinal digestibility between rations with the same kind of roughage. Expressed as the amount entering the small intestine, however, the starch digestibilities for the highconcentrate ration were higher than those for the high-roughage ration, whichever the roughage consumed. This tendency is in accord with a previous finding ${ }^{4)}$ that high-grain diets have high starch digestion in the small intestine of steers, since carbohydrase activity in the lumen of the ruminant small intestine increases with higher grain intake ${ }^{20)}$. The large-intestinal digestibility of ingested starch was higher for $\mathrm{HH}$ than for $\mathrm{LH}$, and higher for HP than for LP, when expressed as either percentage of the amount consumed or entering large intestine.

The small-intestinal and large-intestinal 
digestibilities of starch infused into the abomasum are shown in Table 4. The smallintestinal digestibility of infused starch became lower in the order LH, HP, HH and LP. In reverse order, the large-intestinal digestibility tended to be greater ; thereby, the total intestinal digestibility was over $93 \%$ in all cases, and not different among the rations. The average digestibility of infused starch in the small intestine was $71 \%$, close to the figure obtained in a similar experiment ${ }^{15)}$ in which twice as much starch as in this trial was infused, and was also higher than that in steers upon intermittent administration ${ }^{14)}$. The latter discrepancy may have resulted from the different procedures used for starch infusion.

It is noteworthy that the digestibility of the infused starch in the small intestine varied substantially among the rations used. As a significant influence of fiber on intestinal starch digestion has been found ${ }^{87}$, a relationship between NDF entering the small intestine and infused starch digestibility in the small intestine can be considered: the starch digestibility, which individually ranged from $73.3 \%$ to $92.8 \%$ except for LP, decreased with the increase of $\mathrm{NDF}$, giving a negative correlation of $-0.66 \quad(\mathrm{P}<0.05, \mathrm{n}=12)$. When LP was included, however, there was a positive correlation of $0.44(P>0.05, n=16)$ between NDF and starch digestibility. Subsequently, NDF entering the small intestine is partly responsible for the variable starch digestion, possibly by increasing the rate of starch passage ${ }^{8)}$ and by interfering with enzymatic action ${ }^{19}$.

The small-intestinal digestibility of infused starch for LP was $45 \%$ of cosiderable low mean in comparison with $75 \%, 79 \%$ and $86 \%$ for $\mathrm{HH}, \mathrm{HP}$ and $\mathrm{LH}$, respectively. Viscosity may be of some significance for the digestion of $\operatorname{starch}^{6)}$. In fact, the appreciable high viscosity of the abomasum digesta for LP observed but not measured during sampling, might have caused the low digestibility due to interference with enzymatic hydrolysis in the lumen of the small intestine. Of course, possible effects of other factors cannot be excluded, for example ruminal fermentation products $^{24)}$.

The ingested starch digestibility in the small intestine (as a percentage of the amount entering, Table 4) was lower compared with that for infused starch except LP. The presumed cause is the partial degradation in the rumen for ingested starch. Additionally, the difference in properties between dietary starch and purified starch may affect the small intestinal digestion, because the former contains other components such as the protein matrix which binds starch granules and limits attach by enzymes ${ }^{18}$.

$\alpha$-Glucoside fractions in ileal digesta

The $\alpha$-glucoside fractions in the terminal ileum digesta are shown in Table 5. The glucan content in the $\alpha$-glucoside without starch infusion was lower for LP than for $\mathrm{HH}$. Dextrin content tended to be inversely correlated with the glucan content: dextrin was lower for $\mathrm{HH}$ than for LP. While sheep were infused starch, glucan and dextrin contents in the terminal ileum were similar to those in a non-infused state, except for LP. The glucan content for LP with starch infusion was largely increased, but the dextrin content was decreased. This suggests that the depression of starch digestibility in the small intestine for LP with starch infusion was caused by lower activity of $\alpha$-amylase.

MAYES and $\emptyset_{\text {RSKOV }}{ }^{15)}$ have indicated maltase to be an enzyme limiting starch digestion in the small intestine of sheep infused gelled starch. However, they ${ }^{15)}$ have also indicated that raw starch digestion in the small intestine was limited by the amount of pancreatic amylase secreted. Therefore, $\alpha$-amylase may be the primary enzyme limiting starch digestion when raw starch is present in the small intestine.

Glucose content was very low, regardless of the ration, but it was increased slightly with 
Table 5. $\alpha$-Glucoside fractions of digesta in terminal ileum of sheep fed rations with or without starch infusion

\begin{tabular}{|c|c|c|c|c|}
\hline \multirow{2}{*}{ Item } & \multicolumn{4}{|c|}{ Treatments } \\
\hline & $\mathrm{HH}$ & $\mathrm{LH}$ & $\mathrm{HP}$ & LP \\
\hline & & 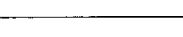 & $=0$ & \\
\hline \multicolumn{5}{|c|}{ Without infusion } \\
\hline Glucan & $62.7 \pm 8.0^{a}$ & $50.0 \pm 15.8^{a b}$ & $54.9 \pm 10.1^{\mathrm{ab}}$ & $38.9 \pm 10.6^{b}$ \\
\hline Dextrin & $36.2 \pm 8.2^{\mathrm{a}}$ & $48.8 \pm 16.0^{\mathrm{ab}}$ & $44.4 \pm 9.7^{a b}$ & $60.3 \pm 10.7^{b}$ \\
\hline Glucose & $1.1 \pm 0.3$ & $0.9 \pm 0.2$ & $0.7 \pm 0.3$ & $0.8 \pm 0.3$ \\
\hline \multicolumn{5}{|c|}{ With infusion } \\
\hline Glucan & $68.1 \pm 5.1^{\mathrm{a}}$ & $46.8 \pm 12.6^{b}$ & $57.5 \pm 4.3^{\mathrm{ab}}$ & $67.4 \pm 9.1^{\mathrm{ab}}$ \\
\hline Dextrin & $24.5 \pm 8.7^{\mathrm{a}}$ & $48.6 \pm 13.5^{b}$ & $37.8 \pm 3.7^{\mathrm{ab}}$ & $29.3 \pm 9.4^{\mathrm{ab}}$ \\
\hline Glucose & $7.4 \pm 4.6$ & $4.7 \pm 1.7$ & $4.7 \pm 1.8$ & $3.3 \pm 0.8$ \\
\hline
\end{tabular}

Figures are mean values \pm standard deviation for 4 sheep.

${ }^{a}$ " Mean values in the same row with different superscripts differ significantly $(P<0.05)$.

Table 6. Blood serum glucose levels with and without starch infusion in sheep given different rations

\begin{tabular}{|c|c|c|c|c|}
\hline \multirow{2}{*}{ Item } & \multicolumn{4}{|c|}{ Treatments } \\
\hline & $\mathrm{HH}$ & LH & $\mathrm{HP}$ & $\mathrm{LP}$ \\
\hline \multirow{2}{*}{\multicolumn{5}{|c|}{ Without infusion }} \\
\hline & & & & \\
\hline 30 min before feeding & $59.1 \pm 3.0^{a}$ & $72.7 \pm 3.8^{b}$ & $59.4 \pm 4.7^{\mathrm{a}}$ & $55.0 \pm 1.8^{\circ}$ \\
\hline $3 \mathrm{~h}$ after feeding & $60.4 \pm 2.1^{a}$ & $77.8 \pm 4.6^{b}$ & $62.7+2.1^{a}$ & $55.0+2.2^{c}$ \\
\hline \multicolumn{5}{|l|}{ With infusion } \\
\hline $30 \mathrm{~min}$ before feeding & $67.1 \pm 2.7^{\mathrm{a}}$ & $77.7 \pm 4.0^{b}$ & $70.3 \pm 4.4^{\mathrm{a}}$ & $60.6 \pm 4.2^{c}$ \\
\hline $3 \mathrm{~h}$ after feeding & $66.4 \pm 3.9^{\mathrm{a}}$ & $77.1 \pm 3.1^{0}$ & $68.4 \pm 4.9^{a}$ & $60.1 \pm 2.6^{c}$ \\
\hline
\end{tabular}

Figures are mean values \pm standard deviation for 4 sheep.

$a, b, c$ Mean values in the same row with different superscripts differ significantly $(P<0.05)$.

starch infusion.

Blood serum glucose

Blood serum glucose levels are shown in Table 6. There was no difference between sampling times of blood for each ration. The serum glucose level without starch infusion was higher in $\mathrm{LH}$ than in $\mathrm{HH}$ and higher in $\mathrm{HP}$ than in LP, which showed the lowest value among the rations. The level in sheep given LH was highest regardless of starch infusion. When sheep were fed the other rations, however, the serum glucose levels increased with starch infusion. This increase probably reflects the absorption of glucose as a product of enzymatic carbohydrolysis of starch in the small intestine ${ }^{11)}$. As propionic acid produced in the rumen is a major precursor of glucose and seems to increase insulin secretion in ruminants $^{4,5)}$, the difference of serum glucose level among the rations may be caused by propionic acid absorbed from rumen, glucose absorbed from small intestine and hormonal control.

In conclusion, it has been suggested that starch digestion is not affected by other ingested components through the whole intestine, but the small-intestinal digestion of starch is variable and partially influenced by 
fiber ingested simultaneously.

\section{References}

1) Alwash, A.H. and P.C. Thomas, The effect of the physical form of the diet and the level of feeding on the digestion of dried grass by sheep. J. Sci. Food Agric., 22 : 611-615. 1971.

2) Armstrong, D.G. and R.R. Smithard, The fate of carbohydrates in the small and large intestines of the ruminant. Proc. Nutr. Soc., 38 : 283-294. 1979.

3) BLACK, J.L., A theoretical consideration of the effect of preventing rumen fermentation on the efficiency of utilization of dietary energy and protein in lambs. Br. J. Nutr., 25: 31-55. 1971.

4) Clary, J.J., G.E. Mitchell, Jr., C.O. LitTle and N.W. BRADley, Pancreatic amylase activity from ruminants fed different rations Can. J. Physiol. Pharmacol., 47 : 161-164. 1969.

5) De Jong, A., Patterns of plasma concentrations of insulin and glucagon after intravascular and intraruminal administration of volatile fatty acids in the goat. J. Endocr., $92:$ 357-370. 1982.

6) GEE, J.M. and I.T. JoHNSON, Rate of starch hydrolysis and changes in viscosity in a range of common foods subjected to simulated digestion in vitro. J. Sci. Food Agric., 36: 614-620. 1985.

7) Goering, H.K. and P.J., VAN SoAst, Forage fiber analyses (apparatus, reagents, procedures, and some applications). Agriculture Handbook no. 379, USDA U.S. Government Printing Office. Washington, D.C. 1970 .

8) Goetsch, A.L., F.N. Owens, M.A. Funk and B.E. DORAN, Effects of whole or ground corn with different forms of hay in $85 \%$ concentrate diets on digestion and passage rate in beef heifers. Anim. Feed Sci. Technol, 18: 151-164. 1987.

9) Hase, S. and T. Yasui, Studies on determination of starch in agricultural products. 1. Examination of the enzymatic method using glucoamylase. Rept. Natl. Food Res. Inst., 36 : 98-103. 1980.

10) Hoover, W.H., Chemical factors involved in ruminal fiber digestion. J. Dairy Sci., 69 : 2755-2766. 1986.
11) JANES, A.N., T.E.L. WeEKS and D.G. Armstrong, Absorption and metabolism of glucose by the mesenteric-drained viscera of sheep fed on dried-grass or ground, maize-based diets. Br. J. Nutr, $54:$ 449-458. 1985.

12) Kabasakalian, P., S. Kalliney and A. WestcotT, Enzymatic blood glucose determination by colorimetry of $\mathrm{N}, \mathrm{N}$-diethylaniline-4-aminoantipyrine. Clin. Chem., 20: 606-607. 1974.

13) Leng, R.A., Modification of rumen fermentation, in Nutritional limits to animal production from pastures. (HACKER, J.B. ed) 427-453. Commonwealth Agricultural Bureaux. Slough. 1981.

14) Litrue, C.O., G.E. Mitchell, Jr. and C.M. Reitnour, Postruminal digestion of corn starch in steers. J. Anim. Sei., $27:$ 790-792. 1968.

15) Mayes, R.W. and E.R. Ørskov, The utilization of gelled maize starch in the small intestine of sheep. Br. J. Nutr., 32:143153. 1974.

16) National Research Council, Nutrient requirements of sheep, 5 th rev. ed. National Academy Press. Washington, D.C. 1975.

17) Ørskov, E.R., C. Fraser and R.N.B. KAY, Dietary factors influencing the digestion of starch in the rumen and small and large intestine of early weaned lambs. Br. J. Nutr., 23 : 217-226. 1969.

18) OWEns, F.N., R.A. ZINN and Y.K. KIM, Limit to starch digestion in the ruminant small intestine. J. Anim. Sci., 63 : 16341648. 1986.

19) Schneeman, B. and D. Gallaher, Effects of dietary fiber on digestive enzymes. in Handbook of dietary fiber in human nutrition. (SPILLER, G.A. ed) 143-164. CRC Press. Florida. 1986.

20) Srr Elkhatim, M.M. and A.M. Osman, Effect of concentrate feeding on the bovine intestinal and pancreatic carbohydrases. Evidence of induced increase in their activities. Comp. Biochem. Physiol, $74 \mathrm{~A}$ : 275-281. 1983.

21) Smrrh, R.H., Nitrogen metabolism in the ruminant stomach. in Protein metabolism in farm animals. (Bock, H.-D., B.O. Eggum, A.G. Low, O. Simon and T. ZsBrowska ed) 165-203. Oxford University Press Oxford. 1989. 
22) Taniguchi, K., M. Sugihara, Y. Yamatani and I. Otani, Effects of starch supplementation on the fiber digestibility and the chewing time of hay consumed by sheep. Jpn. J. Zootech. Sci., 57 : 1046-1049. 1986.

23) Taniguchi, K., S. Miyake, T. Obitsu and Y. Yamatani, Effects of ruminal undiges. ted fiber on intestinal starch digestion in sheep fed different rations and with starch infusion into the abomasum. Asian Aust. J. Anim. Sci., 2 : 353-354. 1989.

24) TAYLOR, R.B., Pancreatic secretion in the sheep. Res. Vet. Sci., 3:63-77. 1962.

25) Theurer, C.B., Grain processing effects on starch utilization by ruminants. J. Anim.
Sci., 63 : 1649-1662. 1986.

26) Tucker, R.E., G.E. Mitchell, Jr. and C.O. LitTle, Ruminal and postruminal starch digestion in sheep. J. Anim. Sci, $27: 824^{-}$ 826. 1968.

27) Yoshida, M., K. Kosaka, S. Horir and K. KAMEOKA, A new procedure for the determination of chromic oxide with potassium phosphate reagent. Jpn. J. Poultry Sci., 4 : 24-29. 1967.

28) ZINN, R.A. and F.N. Owens, Influence of feed intake level on site of digestion in steers fed a high concentrate diet. J. Anim. Sci., 56 : 471-475. 1983.

\title{
粗濃比の異なる飼料給与下での羊の第四胃内 デンプン注入に伴う腸内デンプン消化
}

\author{
谷口幸三・三宅＼cjkstart聡・小匮剛人・山谷洋二
}

広島大学生物生産学部，東広島市 724

羊の小腸内デンプン消化に及ぼす給与飼料の影響，特に紻維成分の影響を調べることを目的として実 験を行なった。第四胃および回腸末端にカニューレを装着した羊 4 頭を供試し，給与飼料には粗飼料源 として細切したイタリアンライグラス乾草あるいはアルファルファミールペレットを、デンプン源とし て㸮砕トウモロコシを用い, 粗濃比を $7: 3$ 上 $3: 7$ (可消化エネルギー比) とする都合 4 種類の飼料処 理を施した，各飼料給与時における胃，小腸，大腸での各成分消化率を湘定し，さらに第四胃内に精製 デンプン(コーンスターチ) を平均 $113 \mathrm{~g} /$ 日注入し，デンプンの腸内消化と絨維量との関係を検討し た。その結果，粗飼料割合が高いと経口掑取デンプンの胃内消化率は低下し，またデンプン移行量に対 する小腸内消化率も低かった。一方，経口掑取デンプンの大腸内消化率は，粗飼料割合が高い場合に， 高くなったか，金消化管消化率は，胃内消化率の占める割合が高いために低くなった．注人デンプンの 小晹内消化率は，濃厚飼料多給下でアルファルファミールペレットを給与した場合を除けば，給与飼料 によって 75〜86\%の範囲内で変動し，小腸移行織維量が增えると低下する傾向にあった。しかし洽厚 飼料多給下のアルファルファミールペレット給与により，小腸内移行纎維量が最も少なかったにもかか

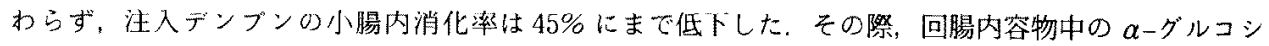
ドのうち高分子分画が增えたので，小腸内での $\alpha$ ーアミラーゼ作用の阿かったことが示唆された，注入 デンプンの大腸内消化率は，小腸内消化率が低いほど代償的に高くなる傾问にあり，全腸管消化率は飼 料処理による影響がなかった，以上のことから，羊の全腸管内でのデンプン消化率は給与飼料の影響を あまり受けないが，小腸内消化率は影響を受けやすいと考元られる。

日畜会報，62 (3)：253-262，1991 